\title{
Seasonal variation in natural mortality factors of Tuta absoluta (Lepidoptera: Gelechiidae) in open-field tomato cultivation
}

\author{
Leandro Bacci ${ }^{1}$ (D) | Ézio Marques da Silva ${ }^{2}$ | Júlio Cláudio Martins ${ }^{3}$ (D) | \\ Marianne A. Soares ${ }^{4}$ | Mateus Ribeiro de Campos ${ }^{5}$ (D) Marcelo Coutinho Picanço ${ }^{6}$
}

${ }^{1}$ Departamento de Engenharia Agronômica, Universidade Federal de Sergipe, São Critovão, Brazil

${ }^{2}$ Instituto de Ciências Agrárias, Universidade Federal de Viçosa, Viçosa, Brazil

${ }^{3}$ Instituto Federal de Educação, Ciência e Tecnologia Baiano, Campus Teixeira de Freitas, Teixeira de Freitas, Bahia, Brazil

${ }^{4}$ Departamento de

Entomologia, Universidade Federal de Lavras, Minas Gerais, Brazil

5INRA (French National Institute for Agricultural Research), CNRS, UMR 1355-7254, Institut Sophia Agrobiotech, Université Côte d'Azur, Sophia Antipolis, France

${ }^{6}$ Departamento de

Entomologia, Universidade Federal de Viçosa, Viçosa, Brazil

\section{Correspondence}

Júlio Cláudio Martins, Instituto Federal de Educação, Ciência e Tecnologia Baiano, Campus Teixeira de Freitas, Teixeira de Freitas, Bahia, Brazil.

Email: julioufv@gmail.com

\begin{abstract}
The seasonal variation in natural mortality of phytophagous insects is determined by the relative importance of biotic and abiotic factors in agroecosystems. Knowledge regarding these factors throughout the year represents a key concern for IPM programmes. Seasonal population fluctuations of tomato pinworm, Tuta absoluta, led to an investigation of its natural mortality factors during the rainy season when the population level is low and during the dry season when population peaks occur. The aim of this study was to verify the seasonal variation in T. absoluta mortality factors in tomato crops. Immature stages of T. absoluta were obtained from laboratoryrearing in the laboratory. These were taken to the field and monitored over two years. The mortality causes for each stage of insect development from egg to adult were assessed daily. Multiple biotic and abiotic mortality factors affected the immature T. absoluta stages such as rainfall, physiological disturbances, diseases, parasitoids and predators. The key T. absoluta mortality factor during summer-spring was predation. In addition, larvae predation correlated positively with temperature, wind velocity, photoperiod and rainfall. Nevertheless, during winter-fall, the key mortality factor was parasitism. Therefore, the critical stage for mortality was 3rd- and 4thinstar larvae, being more vulnerable to natural control factors. Finally, the results showed the importance of vertical and horizontal action on natural mortality factors.
\end{abstract}

\section{KEYWORDS}

climatic elements, insect seasonality, parasitoid, physiological disturbance, predator, Tomato borer

\section{1 | INTRODUCTION}

Understanding how agroecosystem components can change the attack intensity of a pest species on its host plant is a key step in the development of integrated pest management (IPM) programmes (Pereira, Picanço, Bacci, Crespo, \& Guedes, 2007; Semeão et al., 2012). This may be even more important when considering a crop system such as tomatoes, where pest insect control interventions are intensively carried out with synthetic insecticide applications. However, in some cases, the desired outcome was not achieved due to control failures and pest resistance to insecticides (Campos, Silva, Silva, Silva, \& Siqueira, 2015; Campos et al., 2014; Gontijo et al., 2013; Roditakis et al., 2015; Silva, Assis, Ribeiro, \& Siqueira, 2016; Silva et al., 2011, 2015; Siqueira, Guedes, \& Picanço, 2000). Therefore, the management practices adopted aim at conserving and increasing the role natural control agents play as agroecosystem components, being able to help to reduce losses due to pest attack. Such practices are environmentally safer and more sustainable since they have low or no negative economic impact on crop production. 
Maintenance of pest population balance can be achieved through the action of several natural mortality factors (Pereira et al., 2007; Semeão et al., 2012). This kind of information can be obtained using ecological life tables from pest studies to determine the critical stage and key mortality factors of a pest (Gonring, Picanço, Guedes, \& Silva, 2003; Pereira et al., 2007; Rosado et al., 2014; Semeão et al., 2012; Silva et al., 2017). Interaction relevance of leafminer in demographic parameters is affected between miners and host plants, such as miners' insects and natural enemies (vertical sources) or in intra- and inter-specific competition, including meteorological factors, such as wind, storms, frosts, heavy rain, moisture and extreme temperatures (horizontal sources; Auerbach, Connor, \& Mopper, 1995). Seasonal variation in agroecosystems, such as rainfall and dramatic maximum/minimum temperature changes, can be the most important factors to reduce insect abundance (Cornell \& Hawkins, 1995). Among the factors involved in natural mortality, natural enemies and climatic variables stand out because they cause mortality during all life cycle stages of insect pests and generally have a great impact on the population dynamics of these organisms (Naranjo \& Ellsworth, 2005). These two groups of mortality factors may present seasonality throughout the crop cycle and during the different seasons (Pereira et al., 2007; Semeão et al., 2012). Therefore, it is important to know the duration and magnitude of these factors at different times, because this information is fundamental for population dynamics studies and sustainable development of pest management programmes.

The tomato pinworm, Tuta absoluta (Meyrick; Lepidoptera: Gelechiidae), is the main tomato pest in South America (Gontijo et al., 2013; Silva et al., 2011). Currently, this pest has been recognized as a worldwide threat to tomato production, being one of the major concerns as a quarantine pest for North American and Asian countries, where the presence of this pest has not yet been confirmed (Biondi, Guedes, Wan, \& Desneux, 2018; Campos, Biondi, Adiga, Guedes, \& Desneux, 2017; Desneux, Luna, Guillemaud, \& Urbaneja, 2011; Desneux et al., 2010). This is a result of the high capacity of $T$. absoluta to cause economic damage to tomato crops due to its larvae attacking various parts of the plant such as the leaves, flowers, stems and especially fruits (Biondi et al., 2018; Galdino et al., 2015; Tropea Garzia, Siscaro, Biondi, \& Zappalà, 2012). The losses caused by T. absoluta to tomato crops, depending on the time of year, may reach $100 \%$ (Desneux et al., 2011; Guedes \& Picanço, 2012). This variability in attack is probably due to the seasonality of its population density. Considering that the harmfulness of T. absoluta depends on its abundance, understanding the mechanisms that determine its population regulation is fundamental in the elaboration of integrated pest management programmes.

Natural enemies and climatic conditions can overcome deficiencies in the method normally used to control T. absoluta, that is, synthetic insecticide applications, which are a critical IPM component that can greatly impact population dynamics of pests. Therefore, the objectives of this study were (a) to investigate the impact of natural mortality factors on T. absoluta; (b) the seasonality of these mortality factors throughout the year in tomato crops; (c) and to determine the relationship between these components of T. absoluta mortality.

\section{2 | MATERIALS AND METHODS}

The study carried out in an experimental tomato crop area in Viçosa, Minas Gerais, Brazil $\left(20^{\circ} 48^{\prime} 45^{\prime \prime} \mathrm{S}, 42^{\circ} 56^{\prime} 15^{\prime \prime} \mathrm{W}\right.$, altitude $600 \mathrm{~m}$ ). The experimental setup was 12 rows with 30 tomato plants $c v$ Santa Clara seedling in a spacing of $0.5 \mathrm{~m}$ between plants and $1 \mathrm{~m}$ between rows in a total area of $180 \mathrm{~m}^{2}$. The experimental area used standard agronomic practices for tomato cultivation; however, no other method to control insects and diseases was used.

Seasonal and natural variabilities in T. absoluta mortality factors were evaluated using ecological life tables for eight different periods over two years. The assessments were performed for four seasons. The periods in each year were chosen to represent different seasons (fall, winter, spring and summer) for the Southern Hemisphere.

\section{1 | Rearing of Tuta absoluta}

The leaves of tomato plants with T. absoluta were collected from commercial crops and taken to the laboratory for study (Silva et al., 2011). A T. absoluta colony was established in the laboratory using a system of four wood cages $(40 \times 40 \times 40 \mathrm{~cm})$, covered with nylon mesh. The laboratory-rearing system consisted of cages for oviposition, 1st- and 2nd-instar larvae, 3rd- and 4th-instar larvae, pupae and adults. The T. absoluta colony in the laboratory was placed under conditions of $25 \pm 2{ }^{\circ} \mathrm{C}$, relative humidity $(\mathrm{RH})$ $75 \pm 5 \%$ and photoperiod of 12:12 (L: D) hr. Larvae were fed with cv. Santa Clara tomato leaves from the greenhouse without insecticide application.

\section{2 | Mating establishment}

Tuta absoluta stages from laboratory-rearing were taken to field and their mortality monitored throughout the seasons. Ten experimental plots were used for each instar, with each plot having a tomato plant at the reproductive stage chosen at random from the crop. Egg and 1st-instar mortality was evaluated on the apical canopy. Second-, third- and fourth-instar T. absoluta mortality was evaluated on the median canopy. These canopy positions were selected for evaluation of mortality, because they are the preferred plant sites for female oviposition (Torres, Faria, Evangelista, \& Pratissoli, 2001). Therefore, ten leaves from the apical canopy (plots with eggs and 1st-instar larvae) and ten from the median canopy with 2nd-, 3rd- and 4th-instar larvae were carefully inspected to the presence of T. absoluta eggs, larvae and pupae using 10× magnifier lens. If any egg, larva or pupa were found, they were removed with the aid of a soft paint brush 
as well as any dust or eggs and larvae of other species that were present on the leaves.

During initial mating establishment, adult couples were kept in the laboratory. After mating, they were taken to field to obtain eggs. Thirty T. absoluta adults were placed in each plot, closed using nylon mesh, and were left for 24 hours for female oviposition. Eggs were counted using a 10× magnifying manual lens, and their positions on the tomato leaf were recorded using schematic drawing. In each plot, were left 150 eggs, totalling 1,500 eggs per season.

Two hundred and fifty larvae from each instar from the T. absoluta colony were used for larval stage establishment. From each instar, 25 larvae/plot were used. They were transferred using a finetipped brush. The different instars were identified through the degree of cuticle sclerotization, body size and larval cephalic capsule (Imenes, Fernandes, Campos, \& Takematsu, 1990). At each larval stage, the insects were collected from the field at the beginning of the change to the next instar. An exception was made for the 4thinstar larvae, which were removed from the field when they presented a pinkish appearance, which is indicative of the change from larval stage to pupae (Imenes et al., 1990). This removal of insects occurred only at the end of the larval 4th instar, before pupal stage, and then, the larvae remained exposure during all the 4th-instar larval stage. This procedure was adopted, because the 4th-instar larvae generally migrate to the soil before they start to pupate.

A total the 300 individuals were selected from the field and grouped into 30 individual/plot to evaluate pupae mortality. The pupae were placed into plastic trays $(5 \times 25 \times 30 \mathrm{~cm})$ with a $1 \mathrm{~cm}$ layer of sand, which were placed underneath the tomato leaves in the pupation cages stored in the laboratory for $24 \mathrm{hr}$. After this period, the sand was sifted, and the pupae removed for use in the field. This was done due to T. absoluta pupae often being found in the soil or in the dry leaflets or stems of tomato plants (Imenes et al., 1990). The pupae from each plot were conditioned in plastic pots $(10 \mathrm{~cm}$ in diameter and $7 \mathrm{~cm}$ of height), perforated on the side and at the base to allow water drainage from the occasional rains that occurred during the experimental period. The pupae were placed inside plastic pots with a thin layer of sand at the bottom of approximately $3 \mathrm{~mm}$ height. Then, the pots were placed at soil level next to the base of the tomato plant. In order to standardize the time of pupae removal from field, a pilot test was performed in the laboratory to measure the time taken for adult emergence.

\section{3 | Assessment of mortality factors}

Tuta absoluta mortality factors were monitored in the field from the beginning of the egg stage to the end of the pupal stage (Pereira et al., 2007; Semeão et al., 2012). Egg stage data were recorded, that is, position, dates and disappearance cause. The rainfall action on mortality of eggs was determined by counting the number of eggs before and after each rainfall event. It was considered a predator attack when eggs were not found in their previously registered positions and there had been no rain between two consecutive assessments. This assumption is plausible since the T. absoluta eggs remain strongly adhered to the leaves making it difficult for the wind to dislodge them. Damaged eggs, which only presented chorion, were considered dead due to predation. The presence of predators on each leaf was recorded, and representative specimens were collected and placed in $70 \%$ ethanol for subsequent identification. The eggs which did not hatch were placed in the glass tube $(10 \mathrm{~cm}$ length and $2 \mathrm{~cm}$ of diameter). The tubes were covered with perforated PVC plastic and stored in the laboratory under conditions of temperature at $25 \pm 0.5^{\circ} \mathrm{C}, \mathrm{RH} 75 \pm 5 \%$ and photoperiod 12:12 (L: D) hr for subsequent assessment of parasitoid emergence. Incubated eggs that did not present parasitoid emergence were considered dead due to inviability.

First-instar larvae mortality was evaluated in two stages: before and after they penetrated the leaves. The time for leaf penetration was 20-45 min (Imenes et al., 1990). Before leaf penetration, 1stinstar larvae that disappeared following rainfall were considered dead due to this factor, whereas in the absence of rainfall, they were considered dead due to predation. After leaf penetration (formation of the mines), larvae that disappeared or mines that were torn were considered dead due to predation. At the end of the 1st-instar stage, all the leaves evaluated at this stage were collected and analysed on a stereoscopic microscope (40× magnification). First-instar larvae that did not show signs of incomplete moulting (adhered to their exuvie) and disease symptoms were considered dead due to unknown factors (Pereira et al., 2007).

Second-, third-, and fourth-instar T. absoluta larvae that were found during mortality assessment dehydrated inside the mines, with ectoparasitoid, ecdysis disturbance or with disease symptoms were considered dead due to predatory bugs. However, T. absoluta larvae with disease symptoms had a mortality factor classified according to the symptoms caused by fungi or bacteria (Gouli, Gouli, \& Marcelino, 2011). Larval mortality due to predation by predatory wasps was determined by the direct observation of this action on the T. absoluta mines which when attacked showed torn or removed surfaces. The mortality caused by other predators was determined by the observation of the direct action of their organisms on the larvae in the field. The same was the case with ectoparasitism, through evidence of larval paralysis and the observation of ectoparasitoids on T. absoluta larvae. Additionally, all the natural enemies found on the leaves were collected and their representative specimens were kept in $70 \%$ ethanol for complete identification. Like the egg stage, the effect of rain on larvae was determined by checking leaves immediately before and after rainfall. The mortality from rainfall was identified in the field by verifying dead larvae in mines flooded with water after the occurrence of this factor or by observation of drowning dead larvae trapped between leaf epidermis as the water evaporated.

The mortality was only attributed to predation when predators were visually observed feeding on egg, larval and pupal stages. Moreover, a parallel experiment was also carried out on the same fields to monitor the activity of the predators and identify the most frequent preying on T. absoluta stages according with the methodology used by Asiimwe et al. (2007). During this time, 24-hr checks 

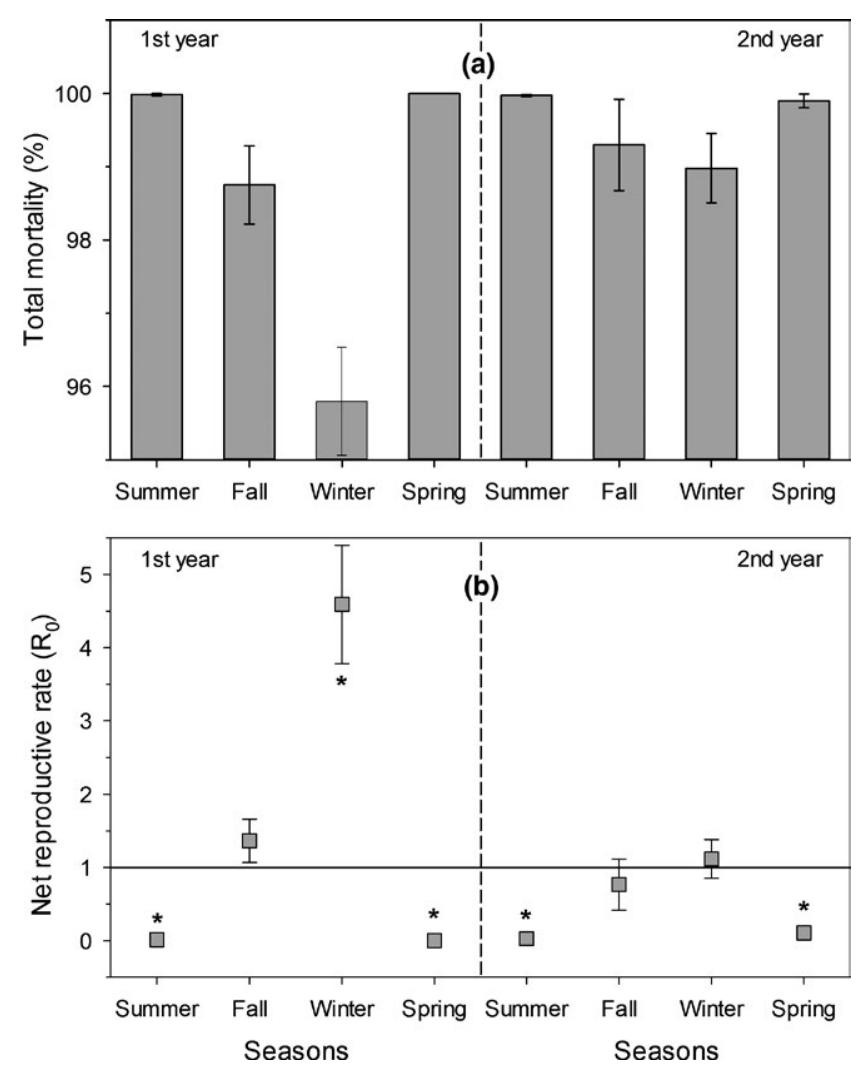

FIGURE 1 Seasonal analysis of Tuta absoluta life history of two parameters. (a) Differences in total mortality between seasons were compared using ANOVA and confidence interval at $95 \%$. (b) Difference in net reproductive rate $\left(R_{0}\right)$ between seasons. For each season, the $R_{0}$ was compared to an equilibrium value $\left(R_{0}=1\right)$ using the $t$ test. In Figure (a) are shown the mean values and $95 \%$ confidence intervals. In Figure (b) are shown the mean values and standard errors. Asterisks indicate that $R_{0}$ for those seasons is different from the equilibrium value

done at 3-hr intervals over a 1-month period at all the evaluated seasons were carried out.

To determine the level of parasitism, the 1st-, 2nd-, 3rd- and 4thinstar larvae alive at the end of each stage were transferred to new tomato leaves and conditioned in 500-ml plastic pots. The plastic pots with a $2-\mathrm{cm}^{2}$ hole in the top were covered with nylon mesh to allow for ventilation. The larvae were kept in the laboratory until the adult stage to verify parasitoid emergence two times a week on the same assessment date. New tomato leaflets were added to feed larvae. Emerged parasitoids were counted and kept in $70 \%$ ethanol for subsequent identification. Emerged T. absoluta adults were counted and removed from the plastic pots. Tomato leaflets were kept in the plastic pots until the T. absoluta adults or parasitoids were no longer observed.

During the pupal stage, natural mortality was determined by directly counting the number of pupae remaining in each plastic pot at the end of the period in the field. The number of pupae dead from predation was determined by the difference between the total initial pupae and pupae remaining in the plastic pots. The mortality was only attributed to predation when predators were visually observed feeding on pupal stage. Remaining pupae were placed in a glass tube similar to the procedure adopted with un-hatched eggs. The pupae were kept in the glass tube for 30 days until T. absoluta adult or parasitoid emergence. After this, the pupae still in the glass tubes were classified as dead due to physiological disturbances (malformation) or rain. Pupae mortality due to rainfall was estimated in the laboratory where the experiment simulating the addition of rainfall to the plastic pupae pots under field conditions was realized. The daily rainfall volumes that occurred during the period that pupae remained in the field were recorded using a gauge installed in the crop. Rainfall action was attributed through the difference of pupae mortality between plastic pots that had added water and those that did not. Pupae that did not emerge T. absoluta adults were classified as dead due to physiological disturbances.

Tuta absoluta parasitoids were identified by Dra. Angélica Maria Penteado Martins Dias of the Universidade Federal de São Carlos, by Dr. Paulo Sérgio Fiuza Ferreira of the Universidade Federal de Viçosa and the Coleoptera by Dr. Ayr de Moura Bello. Others natural enemy specimens were collected, assembled and identified at the Entomology Museum of the Universidade Federal de Viçosa.

\subsection{Statistical analysis}

For the parameters analysed, standard methods for building and ecological analysis of life tables were used (Southwood \& Henderson, 2000). Significant differences in total mortality caused by natural mortality factors throughout the four seasons and the years were analysed using two-way ANOVA (PROC ANOVA) in SAS v.9.2 Software (SAS Institute, 2009). If a significance was detected, post hoc analyses were conducted using confidence interval at $95 \%$ (PROC UNIVARIATE SAS Institute, 2009). Since mortality levels can affect population growth, net reproductive rate $\left(R_{0}\right)$ in each season was estimated and compared to a reference net reproductive rate $\left(R_{0}=1\right)$ using a $t$ test (TTEST Procedure) in the SAS v.9.2. The net reproductive rate data were calculated predicting how the $T$. absoluta population would behave in the light of the seasonality of the mortality factors. The net reproductive rate was estimate by division of egg number expected in the next generation (number of surviving adults in the current mating $\times$ sexual rate $\times$ fecundity) by the initial number of eggs in the current mating. The sex ratio (i.e., number of female/number of female + number of male) was considered to be 0.5973 with fecundity of 183 eggs/female (Mihsfeldt \& Parra, 1999). This information was used because it allows for standardization with respect to sex and fecundity rates for all populations in the different seasons of the year. In this way, it was possible to demonstrate the impact of mortality on population development, without being affected by the reproductive biology of the insect.

The $K$ value was determined to identify the difference between the mortalities by stage and mortality factors within each stage. The $K$ value was calculated using the formula $[K=\log (100 q x)]$, where $100 q x$ is the apparent mortality rate (Southwood \& Henderson, 2000). The significant difference between mortalities by stage and mortality factors within each stage was analysed using one-way 
ANOVA (PROC ANOVA) and, if a significance was detected, post hoc analyses were conducted using confidence interval at 95\% (PROC UNIVARIATE SAS Institute, 2009).

For the T. absoluta critical stage and key mortality factor, a simple linear regression analysis of the partial $K$ values of each stage or each mortality factor as a function of the total $K$ values $(K=\Sigma \mathrm{k})$ for $p<0.05$ was performed for each period. The critical stage or key mortality factor was considered the one with the regression curve showing a higher slope coefficient at $p<0.05$ (Pereira et al., 2007; Semeão et al., 2012). The difference between slopes was verified by the confidence interval at $95 \%$ probability.

The seasonality of mortality factors potentially associated with T. absoluta environmental factors such as wind velocity, rainfall, air temperature and photoperiod were analysed using principal component analysis (PCA) and other natural control agents using the program Canoco 4.5 system (ter Braak \& Smilauer, 2002). The biplot ordering gradient was generated using CanoDraw 3.0. The response gradient was represented by the vectors with the origin at the centre point of the two axes of the sorting diagram. The vector length is proportional to the significance of the variable. Vectors with the same direction and sorting represent a variable with positive correlation, while vectors with the same direction opposite represent a negative correlation. Variables were not correlated when the angle between the vectors is $90^{\circ}$.

\section{3 | RESULTS}

There were significant differences in the total mortality caused by the natural factors, considering different seasons of years $\left(F_{3: 72}=30.20\right.$, $p<0.001)$, between the years $\left(F_{1 ; 72}=16.74, P<0.001\right)$ and in the interaction between seasons and year $\left(F_{3 ; 72}=12.19, p<0.001\right)$.

High T. absoluta mortality rates were observed in the summer and spring and low mortality was observed in the winter and fall during two years as was observed by confidence interval at $95 \%$ (Figure 1a). The T. absoluta net reproductive rate $\left(R_{0}\right)$ was significantly higher than 1 in the winter in the first year ( $t$ test $=4.4, d f=36$, $p=0.001$ ). The $R_{0}$ of T. absoluta was significantly $<1$ in the summer
FIGURE 2 Relative proportion of mortality caused by different mortality factors and represented by $K$-value in each season. The $x$-axis represents the different stages and development stage of Tuta absoluta

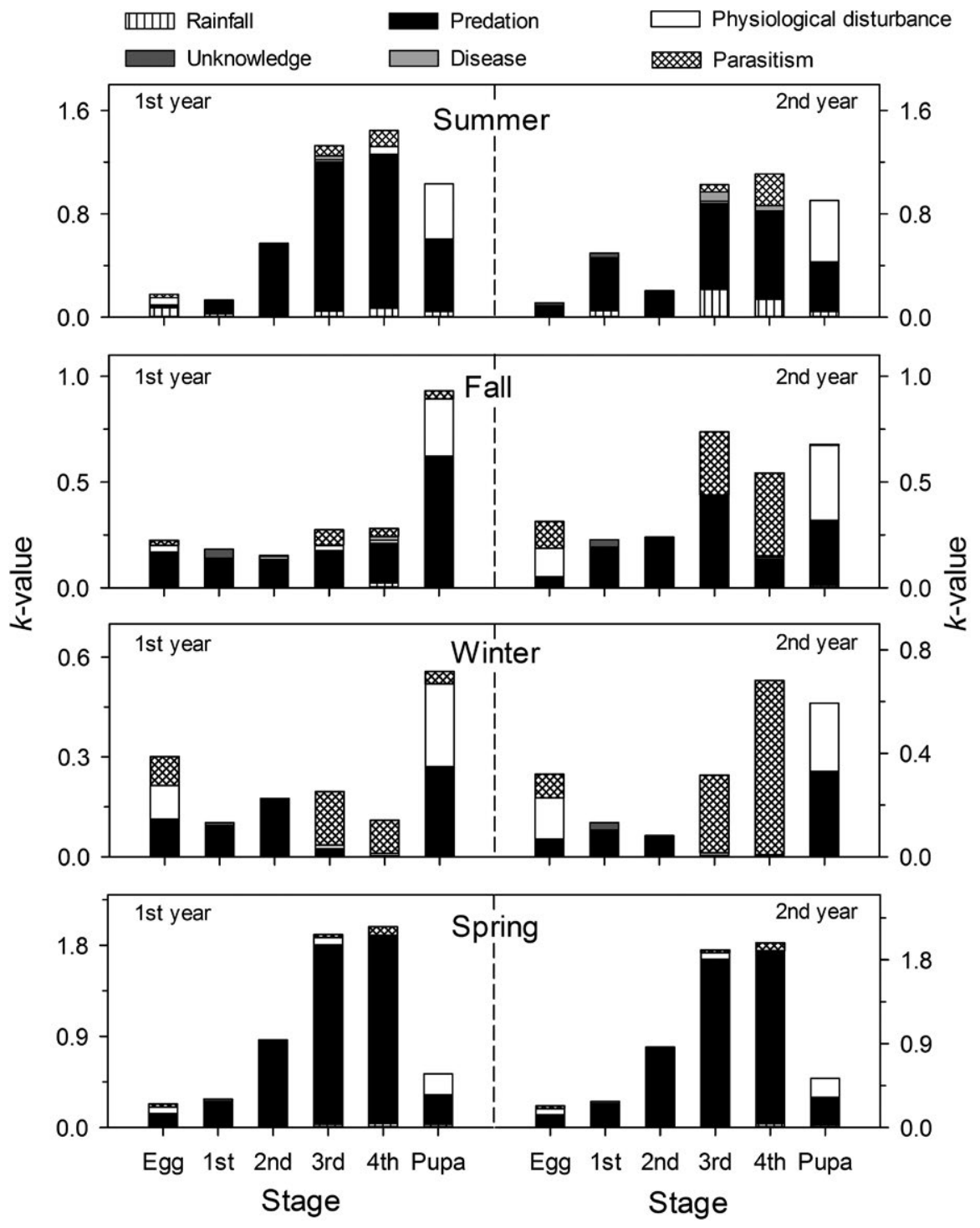




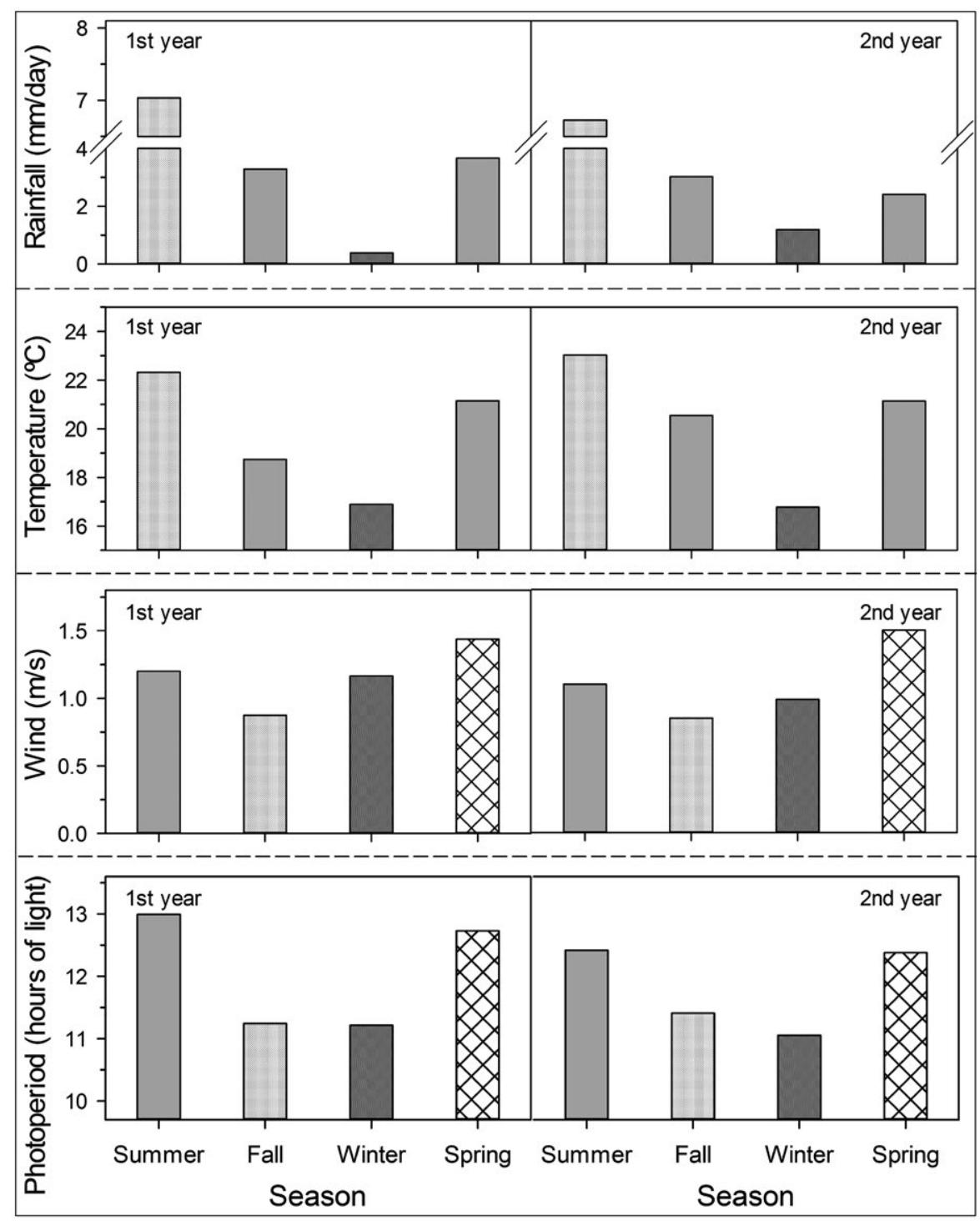

FIGURE 3 Seasonal variation in four environmental factors (rainfall, temperature, wind velocity and photoperiod) in four seasons. These factors were hypothesized affecting the Tuta absoluta survival in tomato crop

$(t$ test $=102.1, p<0.001)$ and spring $(t$ test $=16.9, d f=36, p<0.001)$ for 2 years. In the winter and fall, the $R_{0}$ was similar at 1 (Figure $1 \mathrm{~b}$ ).

Tuta absoluta mortality factors were rainfall, physiological disturbances, diseases, parasitoids and predators. The highest mortality factor for T. absoluta was predation (Figure 2). Predators caused mortality throughout all T. absoluta stages. Eighteen specimens were observed preying on T. absoluta. The predators from the eggs were from the thrip family: Phaleothripidae, the pirate bugs Blaptostethus pallescens Poppius, Orius tristicolor White, and Amphiareus constrictus (Stål) (Heteroptera: Anthocoridae), and Annona bimaculate Distant and Hyaliodocoris insignis (Stål) (Heteroptera: Miridae), larvae of Episyrphus sp. (Diptera: Syrphidae), adults of Acanthinus sp. (Coleoptera: Anthicidae) and the ladybirds Cycloneda sanguinea (Linnaeus), Psyllobora lenta Mulsant, Scymnus sp. and Hyperaspis sp. (Coleoptera: Coccinellidae). The predators from larvae were the wasps Brachygastra lecheguana (Latreille), Polybia scutellaris (White) and Protonectarina sylveirae (Saussure) (Hymenoptera: Vespidae).
The parasitoid caused mortality in all the T. absoluta stages. The T. absoluta egg parasitoid found was Trichogramma pretiosum Riley (Hymenoptera: Trichogrammatidae). The larvae parasitoid found was Bracon sp. (Hymenoptera: Chalcididae) and Pseudapanteles sp. (Hymenoptera: Braconidae).

Less T. absoluta mortality due to predators occurred during winter in comparison with the other seasons $\left(F_{3 ; 76}=92.20, p<0.001\right)$. Rainfall caused 10 times more T.absoluta mortality during summer than in winter/fall and two times more than during spring $\left(F_{3 ; 76}=90.57, p<0.001\right)$. Physiological disturbance caused T. absoluta mortality during the fall and winter $\left(F_{3 ; 76}=3.92, p=0.011\right)$. Tuta absoluta mortality due to disease was high during the summer $\left(F_{3 ; 76}=3.05, p=0.033\right.$; Figure 2).

In summer, the quantity of rainfall was around 2-5 times higher compared with the other seasons. Temperature changes in subtropical regions are generally not drastic. However, they can cause mortality due to cold, although the temperature was colder during 
FIGURE 4 Critical stage (left side) and critical instar (right side) of Tuta absoluta mortality during four seasons. Regression linear analysis of partial $K$ of each instar with a function of total $K(K=\Sigma k)$ at $p<0.05$ was performed at the critical stage with those with a regression curve showing the highest slope coefficient at $p<0.05$. In Figure 4 are shown the slope coefficient of regression curve and confidence intervals of slope coefficient. Asterisks indicate difference in slope coefficient between stages or instar based in the confidence interval at $95 \%$

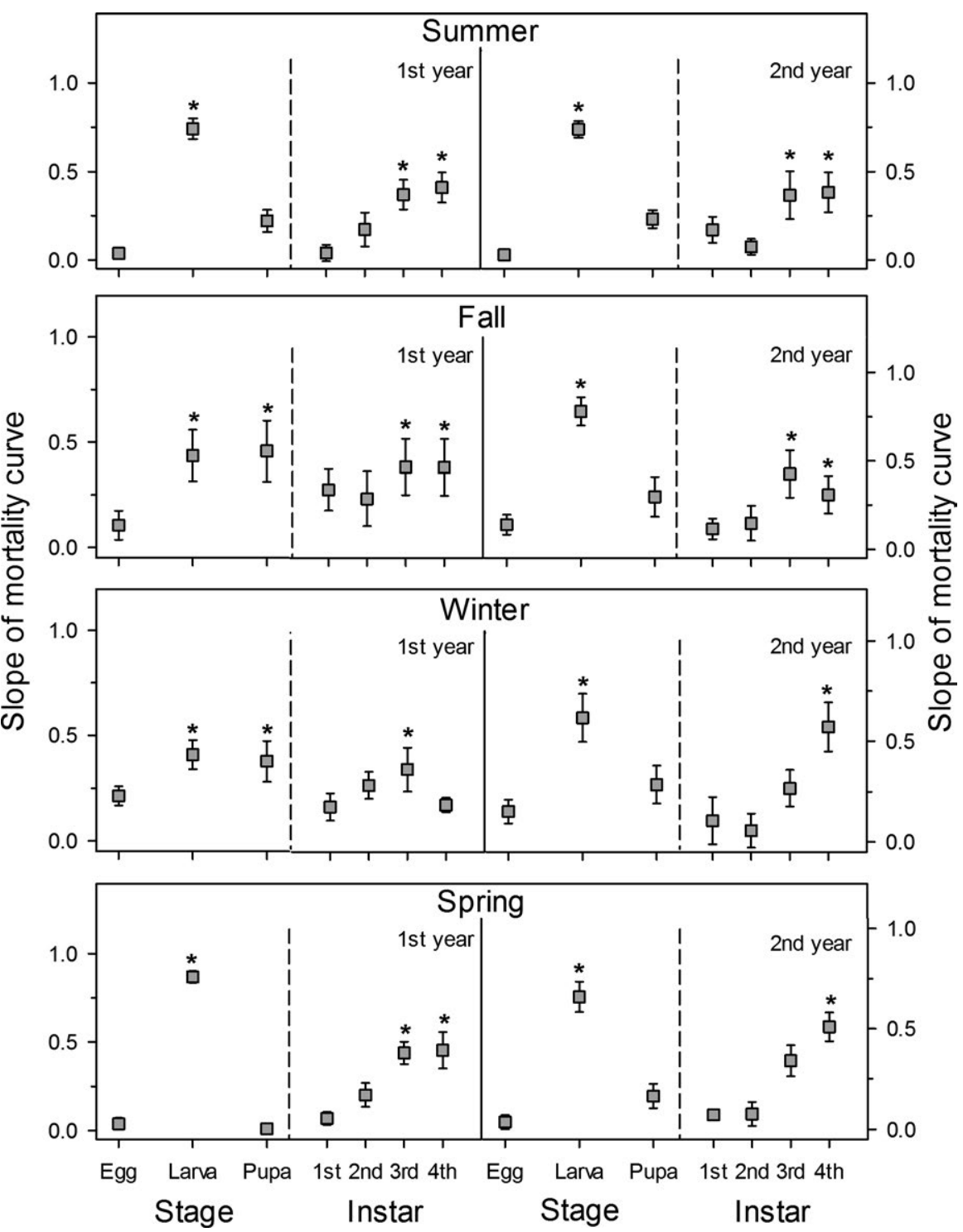

winter, being a temperature that may reduce reproduction, it did not cause mortality (Figure 3). Variable wind velocity was observed (less intense during fall than during spring). Nevertheless, wind velocity could be a factor that caused T. absoluta mortality. The photoperiod was relatively similar between the different study periods (Figure 3 ).

Among T.absoluta stages, the larvae presented the mortality curve with the highest slope. However, this was not observed during fall or winter in the first year when both larvae and pupae presented a mortality curve with a high slope. However, they did not differ from each other. Among T. absoluta larval instar, the 3rd and 4th instar presented a mortality curve with the highest slope. On the other hand, during the winter, the mortality curve with the highest slope was observed in the 3rd instar.Additionally, during spring and winter in the second year, the mortality curve with the highest slope was for the 4th instar (Figure 4). Therefore, these were the critical stages for T. absoluta mortality for each year and season.

Generally, predators were the key T. absoluta mortality factor. Nevertheless, during the winter of the second year the key mortality factor was parasitism. The key factor of T. absoluta mortality during winter in the first year and fall of the second year was physiological disturbances and larval parasitoids (Figure 5).

The PCA model for key T. absoluta mortality factors with the climatic elements generated four axes (Eigenvalue $=0.96$ ) accounting for $99.4 \%$ of variance observed. During the larval stage, predation and parasitism were negatively correlated. During the pupal stage, predation and physiological disturbance were negatively correlated. Predation of 3rd- and 4th-instar T. absoluta larvae (the critical stage of mortality) correlated positively with total mortality and finally correlated negatively with the $R_{0}$. The predation of larvae correlated positively with temperature, wind velocity, photoperiod and rainfall. The opposite was observed with the parasitism of T. absoluta larvae (Figure 6).

\section{4 | DISCUSSION}

Phytophagous insect populations respond idiosyncratically in time and space to a myriad of abiotic and biotic factors leading to seasonal 


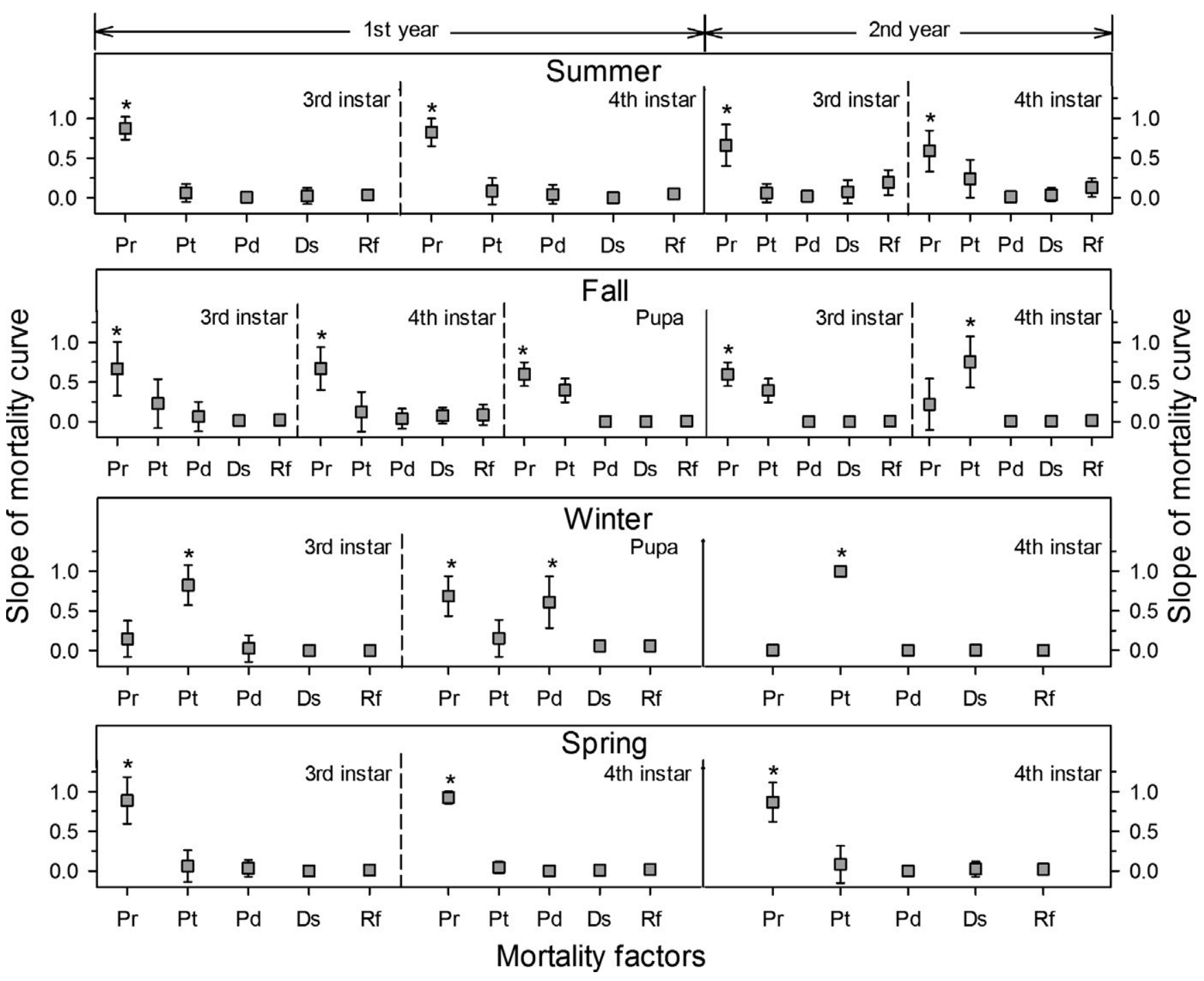

FIGURE 5 Key mortality factors of Tuta absoluta in summer, fall, winter and spring. Regression linear analysis of partial k of each mortality factor as a function of a total $K(K=\Sigma k)$ at $p<0.05$ was performed being the key factor mortality those with a regression curve showing the highest slope coefficient at $p<0.05$. In Figure 5 are shown the slope coefficient of regression curve and confidence intervals of the slope coefficient. Asterisks indicate difference in slope coefficient between stages or instar based in the confidence interval at $95 \%$. $(\mathrm{Pr}=$ predation, $\mathrm{Pt}=$ parasitism, $\mathrm{Pd}=$ physiological disturbance, $\mathrm{Ds}=$ disease and $\mathrm{Rf}=$ rainfall $)$

variation in population density (Campos, Schoereder, \& DeSouza, 2006; Hopkins \& Memmott, 2003; Yarnes \& Boecklen, 2005). In this study, T. absoluta mortality varied seasonally and this variation was regulated by the relative importance of natural mortality factors for this pest that operate during each season of the year. The action of natural T. absoluta control factors caused higher mortality during summer and spring than in fall and winter. This variation in mortality may occur due to differences in precipitation during the summer and spring periods. The results obtained were in agreement with population fluctuation patterns for T. absoluta observed in the tropical region (Castelo Branco, 1992) and reinforce the importance of rainfall as a mortality factor for this pest. In addition to directly affecting mortality, rainfall can cause asynchrony in the emergence of adults and consequently delay mating and reduce female oviposition (Michereff, Vilela, Nery, \& Thiebaut, 2004), therefore playing an important role in population dynamics. Although rainfall was reported as the main factor responsible for the seasonality of phytophagous insects in the tropical regions, other factors such as predators, parasitoids, pathogens and physiological disturbances have a great influence on seasonal variation in T. absoluta populations as was verified in this study.

The T. absoluta population tended to increase during winter and decreased in summer as was observed with the net reproductive rate $\left(R_{0}\right)$ for these periods. These results provided strong evidence for action of natural control factors to maintain T. absoluta populations at a balanced level. Therefore, it may reduce the need for insecticide applications, which are currently the method most used for T. absoluta control (Campos et al., 2014, 2015; Roditakis et al., 2015; Silva et al., 2015, 2016). However, a slight reduction in mortality during fall and winter led to an increase in $R_{0}$, although the 


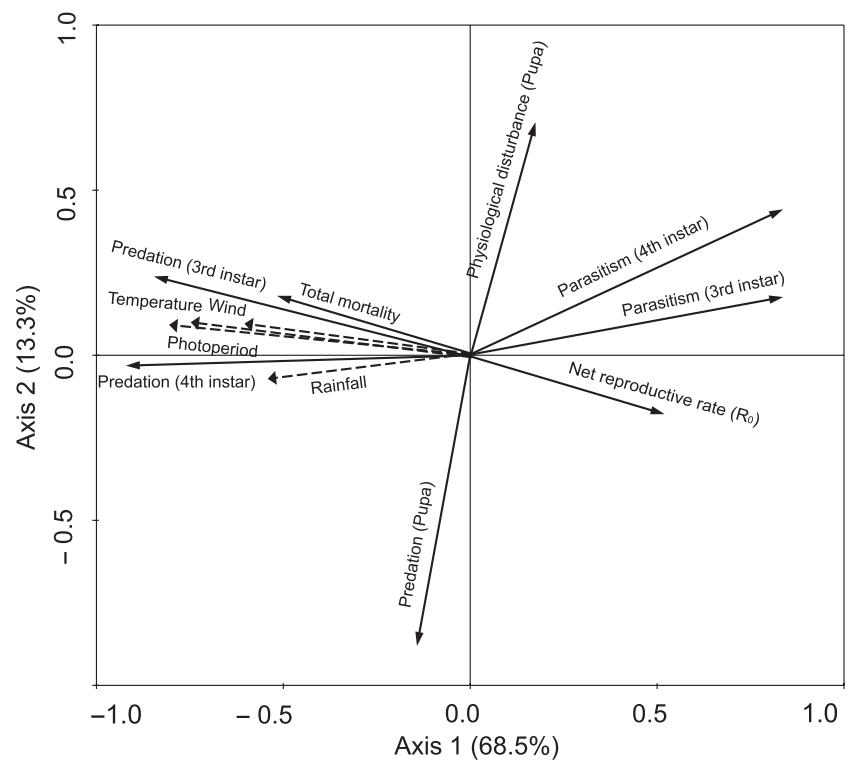

FIGURE 6 Ordination diagram of principal component analysis (PCA) of temperature effect of air $\left({ }^{\circ} \mathrm{C}\right)$, rainfall ( $\left.\mathrm{mm} / \mathrm{month}\right)$, wind velocity $(\mathrm{m} / \mathrm{s}$ ) and photoperiod (hours of light/day) on the different mortality natural factors of Tuta absoluta. The contribution rates of the first 2 principal components were $68.50 \%$ and $13.30 \%$, respectively. Variable with correlation has vectors with opposite direction and orientation. Perpendicular vectors indicate variables independent or no correlated

temperature during these periods was not in optimal for T. absoluta reproduction or survival (Martins et al., 2016). Therefore, in IPM of T. absoluta, strategies that maximize the action of natural mortality factors should be included, especially during fall and winter, because a slight reduction in mortality in these seasons could increase the damage caused by T. absoluta in the following seasons.

Analyses of critical stages and key mortality factors were widely used in ecological life-table studies. The larval stage was the critical mortality stage for T. absoluta and similar results were previously reported in other ecological life-table studies for T. absoluta (Gonring et al., 2003; Pereira et al., 2007). In fact, the larval stage has a longer development period ( 20 days) than other stages such as egg (4 days) and pupae (7 days). Therefore, it could remain exposed for longer to natural mortality factors (Miranda, Picanço, Zanuncio, \& Guedes, 1998). During the larval stage, the $3 r d$ and 4 th instars were the most vulnerable to mortality factors. Vulnerability during this stage could be related to the greater conspicuity of its larvae to natural enemies due to their body size (Cornell \& Hawkins, 1995; Picanço et al., 2011). Another explanation for T. absoluta larvae vulnerability to rainfall action could be due to their sheltering in large mines, which were flooded after rainfall. Therefore, T. absoluta mortality during the final-larval instar reinforces the importance of maintaining an abundance and diversity of natural agents to control this pest.

Several predators such as predatory thrips, ladybugs C. sanguinea, P. lenta, Scymnus sp. and Hyperaspis sp., marmalade hoverfly Episyrphus sp., beetle Acanthinus sp., lacewing Chrysoperla sp. (Neuroptera, Chrysopidae) and small beetles Paederus sp. (Coleoptera: Staphylinidae) were found attacking T. absoluta on tomato plants. The members of Phlaeothripidae, Coccinellidae, Anthicidae and Staphylinidae families have been previously cited as T. absoluta predators (Miranda et al., 1998). Research has been carried out under laboratory conditions to assess the suitability of T. absoluta for the predator Chrysoperla externa (Hagen) (Neuroptera: Chrysopidae; Ghoneim, 2014). While Syrphidae, despite being reported to be a specialist for Hemiptera, may also prey on eggs and small larvae in other insect groups (Medeiros, Sujii, \& Morais, 2009). All the predators are generalists and may exhibit high pest insect predation capacity in a number of agroecosystems (Musser \& Shelton, 2003; Symondson, Sunderland, \& Greenstone, 2002).

Hemiptera from the Anthocoridae and Miridae families have also been reported to be predators of different leaf miners (Arno, Alonso, \& Gabarra, 2003; Legaspi, French, Zuñiga, \& Legaspi, 2001; Passos et al., 2017). Specifically, in the case of T. absoluta, the species already reported were Nesidiocoris tenuis Reuter, Macrolophus pygmaeus Rambur, Dicyphus marrocannus Wagner (Hemiptera: Miridae) and Nabis pseudoferus Remane (Hemiptera: Nabidae; Desneux et al., 2010). Although only these species had been previously reported, in this study other predatory pirate bugs were found such as $B$. pallescens, O.tristicolor, A. constrictus, A. bimaculate and $\mathrm{H}$. insignis (Queiroz, Ramos, Gontijo, \& Picanço, 2015). These predators were observed in high frequency on tomato leaves from which eggs disappeared and were also observed attacking T. absoluta larvae. These Hemiptera may have migrated from weeds present in the growing area searching for food or oviposition sites. The Hemiptera species found in this study may be potential biological control agents for T. absoluta (Calvo, Lorente, Stansly, \& Belda, 2012; Sylla, Brévault, Diarra, Bearez, \& Desneux, 2016). Additionally, other predators such as predatory wasps (B. lecheguana, $P$. scutellaris and $P$. sylveirae) were observed attacking 3 rd- and 4 th-instar T. absoluta larvae, whereas ants such as Solenopsis sp. were observed attacking pupae. The predatory wasps have been considered efficient natural control agents for larvae from several species and other Lepidopteran pests (Gonring et al., 2003; Picanço et al., 2010), including T. absoluta (Picanço et al., 2011). Ants are also predators commonly associated with leaf miners (Urbaneja, Muñoz, Garrido, \& Jacas, 2004; Xiao, Qureshi, \& Stansly, 2007). As a T. absoluta predator, the ants already reported were Pheidole sp. (Hymenoptera: Formicidae), Solenopsis saevissima Smith (Hymenoptera: Formicidae) and Solenopsis geminate (Fabricius) (Hymenoptera: Formicidae; Desneux et al., 2010; Miranda et al., 1998).

Parasitoids observed were Trichogramma pretiosum Riley (Hymenoptera: Trichogrammatidae), Bracon sp., Earinus sp., Pseudapanteles sp. (Hymenoptera: Braconidae) and Conura sp. (Hymenoptera: Chalcididae). Although parasitoids action has not been the most important mortality factor, considering all the periods evaluated, they were present in all the periods, with greater expression in the fall and winter periods and in the 3rd- and 4th-instar larval. Various predators and parasitoids have been reported naturally attacking T. absoluta in tomato crops in Europe and North Africa and more recently in India and South America (Biondi, Desneux, AmiensDesneux, Siscaro, \& Zappalà, 2013; Calvo, Soriano, Stansly, \& Belda, 
2016). Some efforts have targeted the activity of the T. absoluta egg (Cabello et al., 2012; Chailleux et al., 2012; El-Arnaouty et al., 2014; Martins et al., 2017) and larval parasitoids (Biondi et al., 2013; Chailleux, Desneux, Arnó, \& Gabarra, 2014). However, the most cost-effective and successful biological control programmes are those based on the augmentation and/or conservation of Miridae bugs, such as the omnivorous M. pygmaeus and N. tenuis, employed alone or in combination with parasitoids (Chailleux, Biondi, Han, Tabone, \& Desneux, 2013; Chailleux, Bearez, et al., 2013; De Backer et al., 2015; Naselli et al., 2017) or with selective pesticides (Zappala et al., 2012).

The identification of the critical mortality stages, as well as the mortality factors that act during these stages, have direct implications for pest management. In the dry season, when T. absoluta normally presents high population density, pest management programmes could be planned to focus on the key mortality factor responsible for regulating population dynamics during this season. Since natural enemies are the most important factor, conservative biological control would be a strategy to consider. Thus, the population level of natural enemies should be considered during control decision making, to preserve or increase the beneficial action of these organisms in tomato agroecosystems. Therefore, when insecticide use is necessary, selective insecticides should be prioritized to avoid a reduction in natural enemies, as well as the key factors mortality for T. absoluta as the predators and parasitoids (Bacci et al., 2009, 2012). Predators and parasitoids were key mortality factors during spring-summer and fall-winter, respectively. Seasonal variation and natural enemies and their attack intensity suggested a strong potential for the use T. absoluta as a food and climatic influence on its abundance as was evidenced by the correlation between these climatic factors and the occurrence of these natural enemies (Figure 6).

The poor formation of pupae due to physiological disturbances during winter in the first year was a key mortality factor for T. absoluta. The occurrence of this factor may be related to the seasonal variation in climatic elements and their possible effects on the plant quality as a food source for phytophagous insects. Climatic variability may affect metamorphosis regulation by causing changes in the neural and hormonal messengers of the insects (Chapman, 1998). On the other hand, seasonal variations lead to changes in nutritional status and quantity of allelochemicals present in the plant that may cause mortality and physiological disturbances in phytophagous insects (Awmack \& Leather, 2002; Chapman, 1998). However, it should be considered that in other times of year, death occurred due to physiological disturbances, despite not being important to regulate T. absoluta population dynamics. Although the factors related to the host plant reduce the survival of phytophagous insects, this was not detected directly in ecological life-table studies, which implies an underestimation of the bottom-up effect. Nevertheless, mortality from this effect was evident in the initial larval stages of phytophagous insects (Cornell \& Hawkins, 1995). The unknown mortality factor in first-instar T. absoluta larvae may possibly be associated with the characteristics of the host plant. Therefore, the influence of host plant characteristics on T. absoluta survival and fecundity is issues that should be investigated in detail in future studies.

The relationship between the occurrence of natural enemies and climatic variations associated with T. absoluta mortality showed that predation was higher during the periods of increased temperature, photoperiod and incidence of rainfall (summer and spring), in comparison with parasitism (Figure 6). Other studies have also shown a greater action by predators during summer and parasitoids in winter (Pereira et al., 2007; Semeão et al., 2012). The temporal division in natural enemy occurrence could be associated with physiological adaptations of parasitoids to lower temperatures or due to competition between species of the same trophic level that could interact by intraguild predation (Janssen, Pallini, Venzon, \& Sabelis, 1998; Kennedy, 2003; Polis, Myers, \& Holt, 1989), resulting in a reduction in control agent efficiency.

In summary, in this study, it was found that T. absoluta mortality caused by natural control factors was high and variable throughout the seasons. The critical mortality stage was the larval stage, with final-instar larvae being more vulnerable to natural control factors. The key mortality factor during spring-summer seasons was predation, and in fall-winter, it was parasitism and physiological disorders. Finally, the results showed the importance of the vertical and horizontal action of natural mortality factors.

\section{ACKNOWLEDGEMENTS}

The authors would like to thank the National Council for Scientific and Technological Development (Conselho Nacional de Desenvolvimento Científico e Tecnológico-CNPq), the Brazilian Federal Agency for the Support and Evaluation of Graduate Education (Coordenação de Aperfeiçoamento de Pessoal de Ensino Superior-CAPES) and the Minas Gerais State Foundation for Research Aid (Fundação de Amparo à Pesquisa do Estado de Minas Gerais-FAPEMIG) for the financial support provided. We sincerely thank all help provided by colleagues of the Integrated Pest Management Laboratory/UFV.

\section{CONFLICT OF INTEREST}

The authors declare that they have no conflict of interest.

\section{AUTHORS' CONTRIBUTIONS}

Leandro Bacci and Marcelo Coutinho Picanço conceived and designed research. Leandro Bacci, Ézio Marques da Silva, Júlio Cláudio Martins and Mateus Ribeiro Campos contributed to conduction experiments and acquisition of data. Leandro Bacci, Júlio Cláudio Martins and Marcelo Coutinho Picanço analysed data. Leandro Bacci, Júlio Cláudio Martins, Marianne A. Soares and Mateus Ribeiro Campos wrote the manuscript. All authors read, reviewed and approved the manuscript. 


\section{ORCID}

Leandro Bacci iD http://orcid.org/0000-0002-8198-6080

Júlio Cláudio Martins (iD http://orcid.org/0000-0002-0048-707X

Mateus Ribeiro de Campos (D) http://orcid.org/0000-0001-9317-3215

\section{REFERENCES}

Arno, J., Alonso, E., \& Gabarra, R. (2003). Role of the parasitoid Diglyphus isaea and the predator Macrolophus caliginosus in the control of leafminers. IOBC/WPRS Bulletin, 26, 79-84.

Asiimwe, P., Ecaat, J. S., Otim, M., Gerling, D., Kyamanywa, S., \& Legg, J. P. (2007). Life-table analysis of mortality factors affecting populations of Bemisia tabaci on cassava in Uganda. Entomologia Experimentalis et Applicata, 122, 37-44. https://doi. org/10.1111/j.1570-7458.2006.00487.x

Auerbach, M. J., Connor, E. F., \& Mopper, S. (1995). Minor miners and major miners: Population dynamics of leaf-mining insects. In $\mathrm{N}$. Cappuccino, \& P. W. Price (Eds.), Population dynamics: new approaches and synthesis (pp. 83-110). San Diego, CA: Academic Press. https:// doi.org/10.1016/B978-012159270-7/50006-3

Awmack, C. S., \& Leather, S. R. (2002). Host plant quality and fecundity in herbivorous insects. Annual Review of Entomology, 47, 817-844. https://doi.org/10.1146/annurev.ento.47.091201.145300

Bacci, L., Picanço, M. C., Rosado, J. F., Silva, G. A., Crespo, A. L. B., Pereira, E. J. G., \& Martins, J. C. (2009). Conservation of natural enemies in brassica crops: comparative selectivity of insecticides in the management of Brevicoryne brassicae (Hemiptera: Sternorrhyncha: Aphididae). Applied Entomology and Zoology, 44, 103-113. https://doi. org/10.1303/aez.2009.103

Bacci, L., Rosado, J. F., Picanço, M. C., Pereira, E. J., Silva, G. A., \& Martins, J. C. (2012). Concentration-mortality responses of Myzus persicae and natural enemies to selected insecticides. Journal of Environmental Science and Health, Part A, 47, 1930-1937. https://doi.org/10.1080/0 3601234.2012.676494

Biondi, A., Desneux, N., Amiens-Desneux, E., Siscaro, G., \& Zappalà, L. (2013). Biology and developmental strategies of the palaearctic parasitoid Bracon nigricans (Hymenoptera: Braconidae) on the Neotropical Moth Tuta absoluta (Lepidoptera: Gelechiidae). Journal of Economical Entomology, 106, 1638-1647. https://doi.org/10.1603/EC12518

Biondi, A., Guedes, R. N. C., Wan, F. H., \& Desneux, N. (2018). Ecology, worldwide spread, and management of the invasive South American Tomato Pinworm, Tuta absoluta: past, present, and future. Annual of Review Entomology, 63, 239-258. https://doi.org/10.1146/ annurev-ento-031616

ter Braak, C. J. F., \& Smilauer, P. (2002). CANOCO Reference Manual and CanoDraw for Windows User's Guide: Software for Canonical Community Ordination (version 4.5). Ithaca, NY: Microcomputer Power.

Cabello, T., Gallego, J. R., Fernandez, F. J., Gamez, M., Vila, E., Del Pino, M., \& Hernandez-Suarez, E. (2012). Biological control strategies for the South American Tomato Moth (Lepidoptera: Gelechiidae) in greenhouse tomatoes. Journal of Economic Entomology, 105, 20852096. https://doi.org/10.1603/EC12221

Calvo, F. J., Lorente, M. J., Stansly, P. A., \& Belda, J. E. (2012). Preplant release of Nesidiocoris tenuis and supplementary tactics for control of Tuta absoluta and Bemisa tabaci in greenhouse tomato. Entomologia Experimentalis et Applicata, 143, 111-119. https://doi.org/10.111 1/j.1570-7458.2012.01238

Calvo, F. J., Soriano, J. D., Stansly, P. A., \& Belda, J. E. (2016). Can the parasitoid Necremnus tutae (Hymenoptera: Eulophidae) improve existing biological control of the tomato leafminer Tuta aboluta (Lepidoptera: Gelechiidae)? Bulletin of Entomological Research, 106, 502-511. https://doi.org/10.1017/S0007485316000183
Campos, M. R., Biondi, A., Adiga, A., Guedes, R. N. C., \& Desneux, N. (2017). From the Western Palaearctic region to beyond: Tuta absoluta 10 years after invading Europe. Journal of Pest Science, 90, 787-796. https://doi.org/10.1007/s10340-017-0867-7

Campos, M. R., Rodrigues, A. R. S., Silva, W. M., Silva, T. B. M., Silva, V. R. F., Guedes, R. N. C., \& Siqueira, H. A. A. (2014). Spinosad and the Tomato Borer Tuta absoluta: A bioinsecticide, an invasive pest threat, and high insecticide resistance. PLoS One, 9, e103235. https://doi. org/10.1371/journal.pone.0103235

Campos, W. G., Schoereder, J. H., \& DeSouza, O. F. (2006). Seasonality in neotropical populations of Plutella xylostella (Lepidoptera): resource availability and migration. Population Ecology, 48, 151-158. https:// doi.org/10.1007/s10144-005-0250-z

Campos, M. R., Silva, T. B. M., Silva, W. M., Silva, J. E., \& Siqueira, H. A. A. (2015). Spinosyn resistance in the tomato borer Tuta absoluta (Meyrick) (Lepidoptera: Gelechiidae). Journal of Pest Science, 88, 405-412. https://doi.org/10.1007/s10340-014-0618-y

Castelo Branco, M. (1992). Flutuação populacional da traça-do-tomateiro no Distrito Federal. Horticultura Brasileira, 10, 33-34.

Chailleux, A., Bearez, P., Pizzol, J., Amiens-Desneux, E., Ramirez-Romero, R., \& Desneux, N. (2013). Potential for combined use of parasitoids and generalist predators for biological control of the key invasive tomato pest Tuta absoluta. Journal of Pest Science, 86, 533-541. https:// doi.org/10.1007/s10340-013-0498-6

Chailleux, A., Biondi,A., Han, P., Tabone, E., \& Desneux, N. (2013). Suitability of the pest-plant system Tuta absoluta (Lepidoptera: Gelechiidae)-tomato for Trichogramma (Hymenoptera: Trichogrammatidae) parasitoids and insights for biological control. Journal of Economic Entomology, 106, 2310-2321. https://doi.org/10.1603/EC13092

Chailleux, A., Desneux, N., Arnó, J., \& Gabarra, R. (2014). Biology of two key Palaearctic larval ectoparasitoids when parasitizing the invasive pest Tuta absoluta. Journal of Pest Science, 87, 441-448. https://doi. org/10.1007/s10340-014-0557-7

Chailleux, A., Desneux, N., Seguret, J., Do Thi Khanh, H., Maignet, P., \& Tabone, E. (2012). Assessing European egg parasitoids as a mean of controlling the invasive South American Tomato Pinworm Tuta absoluta. PLoS One, 7, e48068. https://doi.org/10.1371/journal. pone. 0048068

Chapman, R. F. (1998). The insects: structure and function. Cambridge, UK: Cambridge University. https://doi.org/10.1017/CBO9780511818202

Cornell, H. V., \& Hawkins, B. A. (1995). Survival patterns and mortality sources of herbivorous insects: some demographic trends. The American Naturalist, 145, 563-593. https://doi. org/10.1086/285756

De Backer, L., Megido, R. C., Fauconnier, M. L., Brostaux, Y., Francis, F., \& Verheggenet, F. (2015). Tuta absoluta-induced plant volatiles: attractiveness towards the generalist predator Macrolophus pygmaeus. Arthropod-Plant Interact, 9, 465-476. https://doi.org/10.1007/s11829015-9388-6

Desneux, N., Luna, M. G., Guillemaud, T., \& Urbaneja, A. (2011). The invasive South American tomato pinworm, Tuta absoluta, continues to spread in Afro-Eurasia and beyond: the new threat to tomato world production. Journal of Pest Science, 84, 403-408. https://doi. org/10.1007/s10340-011-0398-6

Desneux, N., Wajnberg, E., Wyckhuys, K. A., Burgio, G., Arpaia, S., Narváez-Vasquez, C. A., ... Urbaneja, A. (2010). Biological invasion of European tomato crops by Tuta absoluta: ecology, geographic expansion and prospects for biological control. Journal of Pest Science, 83, 197-215. https://doi.org/10.1007/ s10340-010-0321-6

El-Arnaouty, S. A., Pizzol, J., Galal, H. H., Kortam, M. N., Afifi, A. I., Beyssat, V., ... Heikalet, I. H. (2014). Assessment of two Trichogramma species for the control of Tuta absoluta in North African tomato greenhouses. African Entomology, 22, 801-809. https://doi. org/10.4001/003.022.0410 
Galdino, T. V. S., Picanço, M. C., Ferreira, D. O., Silva, G. A. R., de Souza, T. C., \& Silva, G. A. (2015). Is the performance of a specialist herbivore affected by female choices and the adaptability of the offspring? PLoS One, 10, e0143389. https://doi.org/10.1371/journal. pone.0143389

Ghoneim, K. (2014). Predatory insects and arachnids as potential biological control agents against the invasive tomato leafminer, Tuta absoluta Meyrick (Lepidoptera: Gelechiidae), in perspective and prospective. Journal of Entomology and Zoology Studies, 2, 52-71.

Gonring, A. H. R., Picanço, M. C., Guedes, R. N. C., \& Silva, E. M. (2003). Natural biological control and key mortality factors of Diaphania hyalinata (Lepidoptera: Pyralidae) in cucumber. Biocontrol Science and Technology, 13, 361-366. https://doi. org/10.1080/095831503100012435

Gontijo, P. C., Picanço, M. C., Pereira, E. J. G., Martins, J. C., Chediak, M., \& Guedes, R. N. C. (2013). Spatial and temporal variation in the control failure likelihood of the tomato leaf miner, Tuta absoluta. Annals of Applied Biology, 162, 50-59. https://doi.org/10.1111/ aab.12000

Gouli, V., Gouli, S., \& Marcelino, J. (2011). Principal group of infectious insect diseases. In S. Gouli \& J. Marcelino (Eds.), Common infectious diseases of insects in Culture (pp. 7-42). Dordrecht, the Netherlands: Springer Briefs in Animal Sciences. https://doi. org/10.1007/978-94-007-1890-6

Guedes, R. N. C., \& Picanço, M. C. (2012). The tomato borer Tuta absoluta in South America: pest status, management and insecticide resistance. EPPO Bulletin, 42, 211-216. https://doi.org/10.1111/epp.2557

Hopkins, G. W., \& Memmott, J. (2003). Seasonality of a tropical leaf-mining moth: leaf availability versus enemy-free space. Ecological Entomology, 28, 687-693. https://doi.org/10.1111/j.1365-2311.2003.00552.x

Imenes, S. D. L., Fernandes, M. A. U., Campos, T. B. D., \& Takematsu, A. P. (1990). Aspects of the biology and behaviour of the tomato moth Scrobipalpula absoluta (Meyrick, 1917) (Lepidoptera: Gelechiidae). Arquivos do Instituto Biológico, 57, 63-68.

Janssen, A., Pallini, A., Venzon, M., \& Sabelis, M. W. (1998). Review Behaviour and indirect interactions in food webs of plant-inhabiting arthropods. Experimental and Applied Acarology, 22, 497-521. https:// doi.org/10.1023/A:1006089924336

Kennedy, G. G. (2003). Tomato, pests, parasitoids, and predators: Tritrophic interactions involving the genus Lycopersicon. Annual Review of Entomology, 48, 51-72. https://doi.org/10.1146/annurev. ento.48.091801.112733

Legaspi, J. C., French, J. V., Zuñiga, A. G., \& Legaspi, B. C. (2001). Population dynamics of the citrus leafminer, Phyllocnistis citrella (Lepidoptera: Gracillariidae), and its natural enemies in Texas and Mexico. Biological Control, 21, 84-90. https://doi.org/10.1006/ bcon.2000.0907

Martins, J. C., Picanço, M. C., Bacci, L., Guedes, R. N. C., Santana, P. A., Ferreira, D. O., \& Chediak, M. (2016). Life table determination of thermal requirements of the tomato borer Tuta absoluta. Journal of Pest Science, 89, 897-908. https://doi.org/10.1007/s10340-016-0729-8

Martins, J. C., Picanço, M. C., Silva, R. S., Gonring, A. H. R., Galdino, T. V. S., \& Guedes, R. N. C. (2017). Assessing the spatial distribution of Tuta absoluta (Lepidoptera: Gelechiidae) eggs in open-field tomato cultivation through geostatistical analysis. Pest Management Science, 74, 30-36. https://doi.org/10.1002/ps.4664

Medeiros, M. A., Sujii, E. R., \& Morais, H. C. (2009). Effect of plant diversification on abundance of South American tomato pinworm and predators in two cropping systems. Horticultura Brasileira, 27, 300306. https://doi.org/10.1590/S0102-05362009000300007

Michereff, M. F. F., Vilela, E. F., Nery, D., \& Thiebaut, J. T. (2004). Effects of delayed mating and male mating history on the reproductive potential of Leucoptera coffeella (Lepidoptera: Lyonetiidae). Agricultural and Forest Entomology, 6, 241-247. https://doi. org/10.1111/j.1461-9555.2004.00227.x
Mihsfeldt, L. H., \& Parra, J. R. P. (1999). Biologia de Tuta absoluta (Meyrick, 1917) em dieta artificial. Scientia Agrícola, 56, 769-776. https://doi. org/10.1590/S0103-90161999000400002

Miranda, M., Picanço, M.,Zanuncio, J., \& Guedes, R. (1998). Ecological lifetable of Tuta absoluta (Meyrick) (Lepidoptera: Gelechiidae). Biocontrol Science and Technology, 8, 597-606. https://doi.org/10.1080/09583159830117

Musser, F. R., \& Shelton, A. M. (2003). Bt Sweet Corn and selective insecticides: Impacts on pests and predators. Journal of Economic Entomology, 96, 71-80. https://doi.org/10.1603/0022-0493-96.1.71

Naranjo, S. E., \& Ellsworth, P. C. (2005). Mortality dynamics and population regulation in Bemisia tabaci. Entomologia Experimentalis et Applicata, 116, 93-108. https://doi.org/10.1111/j.1570-7458.2005.00297.x

Naselli, M., Biondi, A., Tropea Garzia, G., Desneux, N., Russo, A., Siscaro, G., \& Zappalà, L. (2017). Insights into food webs associated with the South American tomato pinworm. Pest Management Science, 73, 1352-1357. https://doi.org/10.1002/ps.4562

Passos, L. C., Soares, M. A., Costa, M. A., Michaud, J. P., Freire, B. C., \& Carvalho, G. A. (2017). Physiological susceptibility of the predator Macrolophus basicornis (Hemiptera: Miridae) to pesticides used to control of Tuta absoluta (Lepidoptera: Gelechiidae). Biocontrol Science and Technology, 27, 1082-1095. https://doi.org/10.1080/09583157. 2017.1381879

Pereira, E. J. G., Picanço, M. C., Bacci, L., Crespo, A. L. B., \& Guedes, R. N. C. (2007). Seasonal mortality factors of the coffee leafminer, Leucoptera coffeella. Bulletin of Entomological Research, 97, 421-432. https://doi.org/10.1017/S0007485307005202

Picanço, M. C., Bacci, L., Queiroz, R. B., Silva, G. A., Miranda, M. M. M., Leite, G. L. D., \& Suinaga, F. (2011). Social wasp predators of Tuta absoluta. Sociobiology, 58, 621-633.

Picanço, M. C., de Oliveira, I. R., Rosado, J. F., da Silva, F. M., da Costa Gontijo, P., \& Silva, R. S. (2010). Natural biological control of Ascia monuste by the social wasp Polybia ignobilis (Hymenoptera: Vespidae). Sociobiology, 56, 67-76.

Polis, G. A., Myers, C. A., \& Holt, R. D. (1989). The ecology and evolution of intraguild predation: potential competitors that eat each other. Annual Review of Ecology, Evolution, and Systematics, 20, 297-330. https://doi.org/10.1146/annurev.es.20.110189.001501

Queiroz, O. S., Ramos, R. S., Gontijo, L. M., \& Picanço, M. C. (2015). Functional response of three species of predatory Pirate Bugs attacking eggs of Tuta absoluta (Lepidoptera: Gelechiidae). Environmental Entomology, 44, 246-251. https://doi.org/10.1093/ee/nvu026

Roditakis, E., Vasakis, E., Grispou, M., Stavrakaki, M., Nauen, R., Gravouil, M., \& Bassi, A. (2015). First report of Tuta absoluta resistance to diamide insecticides. Journal of Pest Science, 88, 9-16. https://doi. org/10.1007/s10340-015-0643-5

Rosado, J. F., Bacci, L., Martins, J. C., Silva, G. A., Gontijo, L. M., \& Picanço, M. C. (2014). Natural biological control of green scale (Hemiptera: Coccidae): a field life-table study. Biocontrol Science and Technology, 24, 190-202. https://doi.org/10.1080/09583157.2013.855165

SAS Institute (2009) The SAS system for windows, version 9.2. Cary, NC: SAS Institute.

Semeão, A. A., Martins, J. C., Picanço, M. C., Chediak, M., da Silva, E. M., \& Silva, G. A. (2012). Seasonal variation of natural mortality factors of the guava psyllid Triozoida limbata. Bulletin of Entomological Research, 102, 719-729. https://doi.org/10.1017/S0007485312000338

Silva, J. E., Assis, C. P. O., Ribeiro, L. M. S., \& Siqueira, H. A. A. (2016). Field-evolved resistance and cross-resistance of Brazilian Tuta $a b$ soluta (Lepidoptera: Gelechiidae) populations to diamide insecticides. Journal of Economic Entomology, 109, 2190-2195. https://doi. org/10.1093/jee/tow161

Silva, W. M., Berger, M., Bass, C., Balbino, V. Q., Amaral, M. H. P., Campos, M. R., \& Siqueira, H. A. (2015). Status of pyrethroid resistance and mechanisms in Brazilian populations of Tuta absoluta. Pesticide Biochemistry and Physiology, 122, 8-14. https://doi.org/10.1016/j. pestbp.2015.01.011 
Silva, N. R., Campos, S. O., Farias, E. S., Souza, T. C., Martins, J. C., \& Picanço, M. C. (2017). Relative importance of natural enemies and abiotic factors as sources of regulation of mealybugs (Hemiptera: Pseudococcidae) in Brazilian coffee plantations. Annals of Applied Biology, 171, 303-315. https://doi.org/10.1111/aab.12373

Silva, G. A., Picanço, M. C., Bacci, L., Crespo, A. L. B., Rosado, J. F., \& Guedes, R. N. C. (2011). Control failure likelihood and spatial dependence of insecticide resistance in the tomato pinworm, Tuta absoluta. Pest Management Science, 67, 913-920. https://doi.org/10.1002/ps.2131

Siqueira, H. A. A., Guedes, R. N. C., \& Picanço, M. C. (2000). Insecticide resistance in populations of Tuta absoluta (Lepidoptera: Gelechiidae). Agricultural and Forest Entomology, 2, 147-153. https://doi. org/10.1046/j.1461-9563.2000.00062.x

Southwood, T. R. E., \& Henderson, P. A. (2000). Ecological methods. Oxford, UK: Blackwell Science.

Sylla, S., Brévault, T., Diarra, K., Bearez, P., \& Desneux, N. (2016). Life-history traits of Macrolophus pygmaeus with different prey foods. PLoS One, 11, e0166610. https://doi.org/10.1371/journal. pone.0166610

Symondson, W. O. C., Sunderland, K. D., \& Greenstone, M. H. (2002). Can generalist predators be effective biocontrol agents? Annual Review of Entomology, 47, 561-594. https://doi.org/10.1146/annurev. ento.47.091201.145240

Torres, J. B., Faria, C. A., Evangelista, W. S., \& Pratissoli, D. (2001). Within-plant distribution of the leaf miner Tuta absoluta (Meyrick) immatures in processing tomatoes, with notes on plant phenology. International Journal of Pest Management, 47, 173-178. https://doi. org/10.1080/02670870010011091

Tropea Garzia, G., Siscaro, G., Biondi, A., \& Zappalà, L. (2012). Tuta absoluta, a South American pest of tomato now in the EPPO region: biology, distribution and damage. EPPO Bulletin, 42, 205-210. https:// doi.org/10.1111/epp.2556

Urbaneja, A., Muñoz, A., Garrido, A., \& Jacas, J. A. (2004). Which role do lacewings and ants play as predators of the citrus leafminer in Spain? Spanish Journal of Agricultural Research, 2, 377-384. https:// doi.org/10.5424/sjar/2004023-92

Xiao, Y., Qureshi, J. A., \& Stansly, P. A. (2007). Contribution of predation and parasitism to mortality of citrus leafminer Phyllocnistis citrella Stainton (Lepidoptera: Gracillariidae) populations in Florida. Biological Control, 40, 396-404. https://doi.org/10.1016/j. biocontrol.2006.11.011

Yarnes, C. T., \& Boecklen, W. J. (2005). Abiotic factors promote plant heterogeneity and influence herbivore performance and mortality in Gambel'soak (Quercusgambelii). EntomologiaExperimentaliset Applicata, 114, 87-95. https://doi.org/10.1111/j.1570-7458.2005.00226.x

Zappala, L., Bernardo, U., Biondi, A., Cocco, A., Deliperi, S., Delrio, G., ... Siscaro, G. (2012). Recruitment of native parasitoids by the exotic pest Tuta absoluta in Southern Italy. Bulletin of Insectology, 65, 51-61.

How to cite this article: Bacci L, da Silva ÉM, Martins JC, Soares MA, de Campos MR, Picanço MC. Seasonal variation in natural mortality factors of Tuta absoluta (Lepidoptera: Gelechiidae) in open-field tomato cultivation. J Appl Entomol. 2019;143:21-33. https://doi.org/10.1111/jen.12567 